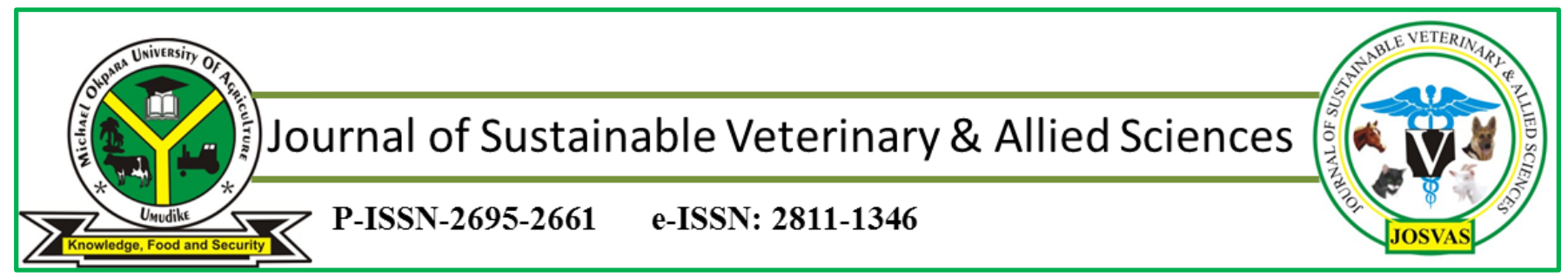

JoSVAS 2021, Vol 1, Issue 2: 145-150

C2021 College of Veterinary Medicine,

Michael Okpara University of Agriculture, Umudike, Nigeria

Original Research Article

\title{
Effect of graded levels of Moringa oleifera leaf meal on serum biochemical parameters of growing male New Zealand white rabbits \\ ${ }^{1 *}$ Egu, U.N., ${ }^{2}$ Otuh, P I., MacNissi C.U. \& Ukwueze, J.I.
}

\author{
${ }^{1 *}$ Department of Veterinary Microbiology, Michael Okpara University of Agriculture,Umudike, Abia State. ${ }^{2}$ Department of \\ Veterinary Microbiology, University of Nigeria Nsukka, ${ }^{3}$ Department of Microbiology, University of Nigeria Nsukka, Nigeria \\ *Corresponding author: ucheegu1@gmail.com; +2348037792462
}

\begin{abstract}
Sixteen (16) growing male New Zealand White rabbits aged 3-4 months were used to determine the effect of graded levels of Moringa oleifera leaf meal (MOLM) on serum biochemical parameters. The rabbits were randomly assigned to four dietary treatment groups $\left(\mathrm{T}_{1}, \mathrm{~T}_{2}, \mathrm{~T}_{3}\right.$ and $\mathrm{T}_{4} ; 4$ rabbits/treatment; 1 rabbit/replicate) in a Complexly Randomized Design (CRD). Treatment one $\left(\mathrm{T}_{1}\right)$ or control contained $0.00 \%$ Moringa oleifera leaf meal while $\mathrm{T}_{2}$ to $\mathrm{T}_{4}$ contained 5.00, 10.00 and $15.00 \%$ MOLM, respectively. The rabbits were fed twice daily (in the morning and evening) while water was provided ad libitum. After 60 days of the feeding trial, blood samples were randomly collected from three rabbits in each treatment group for serum biochemical evaluation of urea, cholesterol, calcium, glucose, alkaline phosphatase, aspartate transaminase and alanine transaminase. The results showed that there were significant differences $(\mathrm{P}<0.05)$ among the treatment groups in all the serum biochemical parameters measured. The findings from this study indicated that the serum biochemical parameters of grower male New Zealand white rabbits could be affected positively when fed feed supplemented with $5.0 \%$ or more of Moringa oleifera leaf meal.
\end{abstract}

Keywords: Leaf meal, Moringa oleifera, rabbits, serum biochemistry

\section{INTRODUCTION}

The New Zealand white rabbits are an exotic breed that survives in tropical environment. It is a heavy breed that weighs about $4.1-4.5 \mathrm{~kg}$ at maturity (Egu, 2016a). They have shinny eyes and white fur that covers every part of the body. They are commercial meat type and reach puberty at about 5-6 months of age (Egu, 2016). Rabbits are highly prolific animals with short generation interval, short gestation period and a good ability to convert a wide range of feedstuff to edible meat (Aduku \& Olukosi, 1990; Olupona \& Balogun, 2004; Akinmutimi \& Anakebe, 2008).

There is need to develop cheaper alternative sources of animal protein such as rabbits to bridge the wide gap that exists between animal protein demand and supply. The current acute shortage of animal protein in Nigeria and increasing demand for livestock products could be alleviated through the production of rabbit meat because it gives lean meat with high nutritional values. According to Spore (2007) and Soyebo (2006), rabbit production has the potential to improve o the nutritionanl value of diet and income of many poor households. The FAO recipe to fight hunger has rabbit as its key component (Prathap and Ponnusaing, 2007).

Feed is a major component affecting net return from livestock enterprise, because $80 \%$ of the total expenditure in terms of cash is spent on feed (Farooq et al., 2001). Plant leaves are commonly processed into leaf meals for use as livestock feed. Examples of the leaf meals which have been widely used in feeding non-ruminant animals include Leucaenia leucocephala, Gliricidia sepium, Seshania seshan and Manihot esculenta (Gadzirayi et al., 2012). Others are Alchonia cordifolia (Wekhe and Njoku, 2000), Ipomea ascarifolia (Maduabuike and Ekenyem, 2000), Azadirachta 
indica (Esonu et al., 2006). Presently, there is a global attention on Moringa (Moringa oleifera) as another promising leaf meal in livestock feeding.

Moringa is drought-tolerant and grows at a rainfall of 250$1500 \mathrm{~mm}$ per year (Martina, 2007). It is rich in nutrients such as protein and minerals. Moringa is one of those plants that have not been studied for many years but now is being investigated for its fast growth, higher nutritional value and increasing utilization as a livestock fodder crop (Nouman et al., 2013). The feeding value of Moringa is reportedly similar to that of soybeans and rap seed meal (Soliva et al., 2004). High nutrient of Moringa makes pregnant women and lactating mothers to use the powdered leaves to enhance their children's nourishment, principally in under developed countries where malnutrition is common (Stephen et al., 2008; Sudha et al., 2010).

The serum is the plasma component of blood which lacks coagulating factors. It is similar to interstitial fluid in which the correct composition of key ions acting as electrolytes is essential for normal functioning of muscles and nerves. Other components in the serum include proteins, antibodies or specialized protein and lipids including cholesterol, which are transported in the serum; and various other substances including nutrients, hormones, and metabolic waste and external substances, such as drugs, virus and bacteria. Blood Protein assists with maintaining $\mathrm{pH}$ and osmotic balance while giving viscosity to the blood. The antibodies re important for defense against viruses and bacteria $\left(\right.$ Martin $^{\mathrm{b}}$, 2007).

In a work carried out by Ewuola et al. (2012) on the hematological and serum biochemical responses of growing rabbits fed graded levels of MOLM, no significant difference was obtained for the Aspartate amino transferase, Alanine amino transferase and Alkaline phosphatase activities between those fed control diet and 5\%, 10\% and 15\% MOLM. Serum biochemical analysis is used to determine the level of heart, liver and kidney function as well as to evaluate protein quality and toxicity of feeds particularly when they affect flood formation and other physiological responses of the animal (Ewuola et al., 2012; Egu, 2010). Moringa has a better protein quality as a result of a high methionine and lysine supply (Ufele et al., 2013). Methionine is the first limiting amino acid and may be particularly important in high energy diets.

This study was carried out to determine the effect of graded levels of Moringa oleifera leaf meal on serum biochemical parameters of growing male New Zealand white rabbits.

\section{MATERIALS AND METHODS}

\section{LOCATION OF STUDY}

The experiment was conducted at the rabbitry unit of the Teaching and Research Farm of the Faculty of Agriculture,
Abia State University, Umudike located within the South East Agro-ecological Zone of Nigeria on latitude $5^{0} 29^{1} \mathrm{~N}$ and longitude $7^{0} 33^{1} \mathrm{E}$ and at an altitude of $122 \mathrm{~cm}$ (400feet) above sea level. The area has an annual temperature of $25-$ $30^{\circ} \mathrm{C}$, relative humidity of between $65-80 \%$, and annual rainfall of $2000-2484 \mathrm{~mm}$; the soil is sandy loamy with average $\mathrm{pH}$ of 5.5 (Adiele et al., 2005).

\section{EXPERIMENTAL DESIGN}

Sixteen (16) growing (3-4 months) healthy New Zealand White rabbits were used for this study. They were assigned to four levels of Moringa oleifera dietary treatment groups represented as $\mathrm{T}_{1}, \mathrm{~T}_{2}, \mathrm{~T}_{3}$ and $\mathrm{T}_{4}$ in a Completely Randomized Design. Each treatment group consisted of 4 rabbits with one rabbit per replicate. The levels of Moringa oleifera leaf meal (MOLM) inclusion in diets were $0.00 \%\left(\mathrm{~T}_{1}\right), 5.00 \%\left(\mathrm{~T}_{2}\right)$, $10.00 \%\left(\mathrm{~T}_{3}\right)$ and $15.00 \%\left(\mathrm{~T}_{4}\right)$. Treatment one $\left(\mathrm{T}_{1}\right)$ served as the control.

\section{PREPARATION OF MORINGA OLEIFERA LEAF MEAL}

Fresh leaves of Moring oleifera were harvested within Umudike near Umuahia, Abia State, Nigeria. The harvested leaves were dried under shade at ambient temperature in order to preserve most of the nutrients, green color and the phyto-chemicals in the leaves according to procedures suggested by Yang and Tsou (2006). The leaflets were stripped from the leaf petioles, washed in $1 \%$ saline solution for 3.5 minutes to remove dirt and pests. The washed leaflets were drained using plastic sieves and spread on trays made with food-grade mesh before taking it to the drier. Drying of leaflets consisted of spreading them thinly on mesh tied on racks in a well-ventilated room. The leaves were turned over once a day to improve the drying. The leaves were dried to $10 \%$ moisture content. The dried Moringa leaves were milled using a stainless steel harmer mill and sieved to $2 \mathrm{~mm}$ particle size. The dried leaf powder was packaged in dry plastic container labelled Moringa oleifera leaf meal (MOLM).

\section{EXPERIMENTAL DIETS}

Four experimental diets (Table 1) were formulated for the rabbits. The MOLM was incorporated into the diets at $0.00 \%, 5.00 \%, 10.00 \%$ and $15.00 \%$ levels represented as $\mathrm{T}_{1}$, $\mathrm{T}_{2}, \mathrm{~T}_{3}$ and $\mathrm{T}_{4}$ respectively. The proximate composition of the diets was obtained using the analytical procedure as described by AOAC (2002).

\section{EXPERIMENTAL ANIMALS AND THEIR MANAGEMENT}

Sixteen (16) growing male New Zealand White rabbits aged 3-4 months were used for this experiment. The rabbits were sourced from the National Root Crop Research Institute Umudike. A 2-week pre-experimental period were allowed 
to enable the rabbits acclimatize to their new environment. Each rabbit was housed in a single hutch of $50 \times 50 \mathrm{~cm}^{2}$ with wire mesh floor and wooden frames. Rabbits and hutches were properly identified according to treatments. The house containing the hutches was naturally ventilated and the rabbits were reared in a clean environment. The necessary routine management practices were maintained. The rabbits were fed commercial concentrate diet only for 2 weeks of acclimatization. Thereafter, freshly cut forage consisting of Panicum maximum, Pennisetum purpureum and Centrosema pubescens were fed as basal diet. The animals were fed 350 $\mathrm{g}$ of feed per rabbit two times daily while water was provided ad libitum. They were fed the experimental diets for 60 days after which data collection and analysis were carried out.

\section{DATA COLLECTION}

\section{BLOOD CHEMISTRY EVALUATION}

At the end of the feeding trial (60 days), three rabbits from each treatment group were randomly selected for bleeding. About $2 \mathrm{ml}$ of blood was aspirated from the marginal ear vein of each rabbit using syringe and needle and poured into plain bottles without ethylene diamine tetra-acethic acid (EDTA) and allowed to coagulate. The bottles of coagulated blood were subjected to standard methods of serum separation by centrifugation at 3000 repm for 5 minutes and the harvested sera were used for evaluation of serum biochemical parameters: urea, cholesterol and glucose were determined following methods described by Baker and Silverton (1986). Aspartate transaminase, Alanine transaminase and Alkaline phosphatase activities were determined using spectrophotometric method as described by Ephraim et al. (2000). The standard flame photometry using Gallenkamp analysis (Egu \& Okonkwo, 2016) was used to determine serum calcium. The experiment was performed in accordance with the ethical guidelines and regulations of the Abia State University, Uturu, Abia State, Nigeria and in accordance with the internationally accepted principles for laboratory animal care and use.

\section{DATA ANALYSIS}

The means of data collected on serum biochemical parameters of growing male New Zealand White rabbits were subjected to one-way analysis of variance (ANOVA) using the technique of Steel and Torrie (2006). Significant treatment means were separated using Duncan's New Multiple Range Test as described by Obi (2002).

\section{RESULTS}

The results of serum biochemical parameters of grower male New Zealand White rabbits fed varying levels of Moringa oleifera leaf meal are shown in table IV.
There were significant differences $(\mathrm{P}<0.05)$ among the treatment groups in serum urea, cholesterol, glucose calcium, Alanine transaminase (ALT), Aspartate transaminase (AST) and Alkaline phosphatase values (ALP).

Rabbits on $\mathrm{T}_{1}$ recorded the highest serum urea (13.41 $\mathrm{mmol} / \mathrm{L})$ and this differed significantly $(\mathrm{P}<0.05)$ from rabbits $\mathrm{T}_{3}$ and $\mathrm{T}_{4}$ which were similar $(\mathrm{P}>0.05)$ to each other and similar $(\mathrm{P}>0.05)$ to rabbits on $\mathrm{T}_{2}$. There was no significant difference $(\mathrm{P}>0.05)$ between rabbits on $\mathrm{T}_{1}$ and $\mathrm{T}_{2}$. The lowest serum urea of $13.34 \mathrm{mmol} / \mathrm{L}$ was observed in rabbits on $\mathrm{T}_{4}$.

Rabbits on $\mathrm{T}_{1}$ and those on $\mathrm{T}_{2}$ recorded the highest value of $2.10(\mathrm{mg} / \mathrm{dl})$ in serum cholesterol and this different significantly $(\mathrm{P}<0.05)$ from rabbits on $\mathrm{T}_{3}$ and $\mathrm{T}_{4}$ which had the lowest serum cholesterol value of $2.00(\mathrm{mg} / \mathrm{dl})$.

Rabbits on $\mathrm{T}_{2}$ recorded the highest serum glucose $(10.50$ $\mathrm{mmol} / \mathrm{L})$ and this differed significantly $(\mathrm{P}<0.05)$ from rabbits on $\mathrm{T}_{3}$ and $\mathrm{T}_{4}$, which were similar $(\mathrm{P}>0.05)$ to each other and similar $(\mathrm{P}>0.05)$ to rabbits on $\mathrm{T}_{1}$ in serum glucose. There was no significant difference $(\mathrm{P}>0.05)$ between rabbits on $\mathrm{T}_{2}$ and $\mathrm{T}_{1}$ in serum glucose. The lowest serum glucose was observed in rabbits on $\mathrm{T}_{4}(9.50 \mathrm{mmol} / \mathrm{L})$.

Rabbits on $\mathrm{T}_{2}$ recorded the highest serum calcium value $(10.10 \mathrm{mmol} / \mathrm{L})$ and this differed significantly $(\mathrm{P}<0.05)$ from rabbits on $\mathrm{T}_{2}(9.70 \mathrm{mmo} / \mathrm{L})$ which were similar $(\mathrm{P}>0.05)$ to rabbits on $\mathrm{T}_{3}$ in serum calcium. There were no significant differences $(\mathrm{P}>0.05)$ among rabbits on $\mathrm{T}_{1}, \mathrm{~T}_{2}$ and $\mathrm{T}_{3}$ in serum calcium. The lowest value in serum calcium was observed in rabbits on $\mathrm{T}_{4}$.

Rabbits on $\mathrm{T} 1$ recorded the highest Alanine transaminase value $(27.97 \mathrm{iu} / \mathrm{L})$ and this differed significantly $(\mathrm{P}<0.05)$ from rabbits on $\mathrm{T} 3$ and $\mathrm{T} 4$ which were similar $(\mathrm{P}>0.05)$ to

Table I: Ingredient composition of experimental diets containing varying levels of Moringa oleifera leaf meal

\begin{tabular}{lcccc}
\hline \multicolumn{5}{l}{ Dietary levels of leaf meal $(\%)$} \\
Ingredients & $\mathrm{T}_{1}$ & $\mathrm{~T}_{2}$ & $\mathrm{~T}_{3}$ & $\mathrm{~T}_{4}$ \\
& $(0.00)$ & $(5.00)$ & $(10.00)$ & $(15.00)$ \\
\hline Maize & 47.00 & 47.00 & 47.00 & 47.00 \\
Moringa & 0.00 & 5.00 & 10.00 & 15.00 \\
leaf meal & & & & \\
Wheat offal & 15.00 & 10.00 & 5.00 & - \\
PKC & 14.00 & 14.00 & 14.00 & 14.00 \\
Soybean & 18.00 & 18.00 & 18.00 & 18.00 \\
Fish meal & 3.00 & 3.00 & 3.00 & 3.00 \\
Bone meal & 2.00 & 2.00 & 2.00 & 2.00 \\
Salt & 0.25 & 0.25 & 0.25 & 0.25 \\
Vita premix & 0.25 & 0.25 & 0.25 & 0.25 \\
Methionine & 0.25 & 0.25 & 0.25 & 0.25 \\
\hline Lysine & 0.25 & 0.25 & 0.25 & 0.25 \\
Total & 100 & 100 & 100 & 100 \\
\hline
\end{tabular}


Table II: Proximate composition of experimental rabbit diets (\%)

\begin{tabular}{lllll}
\multicolumn{5}{c}{ Dietary level of leaf meal \% } \\
\hline Parameters & $\mathbf{T}_{\mathbf{1}}(\mathbf{0 . 0})$ & $\mathbf{T}_{\mathbf{2}}(\mathbf{5 . 0})$ & $\mathbf{T}_{\mathbf{3}}(\mathbf{1 0 . 0})$ & $\mathbf{T}_{\mathbf{4}}(\mathbf{1 5 . 0})$ \\
\hline Protein & $13.77 \pm 0.10$ & $13.94 \pm 0.10$ & $15.11 \pm 0.10$ & $15.69 \pm 0.10$ \\
Fat & $5.44 \pm 0.04$ & $5.70 \pm 0.04$ & $5.77 \pm 0.01$ & $5.81 \pm 0.02$ \\
Fibre & $5.09 \pm 0.02$ & $4.60 \pm 0.35$ & $5.53 \pm 0.01$ & $5.70 \pm 0.04$ \\
Ash & $4.71 \pm 0.01$ & $3.88 \pm 0.04$ & $3.97 \pm 0.01$ & $4.17 \pm 0.01$ \\
Moisture & $10.33 \pm 0.02$ & $10.45 \pm 0.08$ & $10.36 \pm 0.02$ & $10.36 \pm 0.02$ \\
Carbohydrate & $60.65 \pm 0.11$ & $61.43 \pm 0.15$ & $59.26 \pm 0.13$ & $58.27 \pm 0.13$ \\
Energy (kcal/g) & $346.64 \pm 0.28$ & $352.78 \pm 0.16$ & $494.9 \pm 0.16$ & $481.00 \pm 0.11$ \\
\hline Valus
\end{tabular}

Values show means of triplicate analysis \pm standard deviation.
Table III: Proximate composition of fresh Moringa leaf and shade dried Moringa leaf

\begin{tabular}{lll}
\hline Parameters & Fresh (FML) & Dried (DMLM) \\
\hline Protein & $3.79 \pm 0.10$ & $20.94 \pm 0.10$ \\
Fat & $1.35 \pm 0.01$ & $5.09 \pm 0.11$ \\
Fibre & $2.07 \pm 0.12$ & $8.15 \pm 0.03$ \\
Ash & $0.91 \pm 0.03$ & $6.18 \pm 0.04$ \\
Moisture & $70.41 \pm 0.03$ & $10.37 \pm 0.01$ \\
Carbohydrate & $21.46 \pm 0.14$ & $49.27 \pm 0.06$ \\
Energy $(\mathrm{kcal} / \mathrm{g})$ & $113.13 \pm 0.53$ & $326.48 \pm 0.68$ \\
\hline
\end{tabular}

Values show means of triplicate analysis \pm standard deviation. FML: fresh Moringa leaf,

DMLM: dried Moringa leaf meal

Table IV: Serum biochemical parameters of grower male new zealand white rabbits fed graded levels of Moringa oleifera leaf meal

\begin{tabular}{lccccc}
\hline Parameters & $\mathbf{T}_{\mathbf{1}}(\mathbf{0 . 0})$ & $\mathbf{T}_{\mathbf{2}} \mathbf{( 5 . 0 )}$ & $\begin{array}{c}\mathbf{T}_{\mathbf{3}} \\
(\mathbf{1 0 . 0})\end{array}$ & $\begin{array}{c}\mathbf{T}_{\mathbf{4}} \\
(\mathbf{1 5 . 0})\end{array}$ & $\mathbf{S E M}$ \\
\hline $\begin{array}{l}\text { Urea } \\
\text { (mmol/L) }\end{array}$ & $13.41^{\mathrm{a}}$ & $13.38^{\mathrm{ab}}$ & $13.36^{\mathrm{b}}$ & $13.34^{\mathrm{b}}$ & 0.01 \\
$\begin{array}{l}\text { Cholesterol } \\
\text { (mg/dl) }\end{array}$ & $2.10^{\mathrm{a}}$ & $2.10^{\mathrm{a}}$ & $2.00^{\mathrm{b}}$ & $2.00^{\mathrm{b}}$ & 0.03 \\
$\begin{array}{l}\text { Glucose } \\
\text { (mmol/L) }\end{array}$ & $10.00^{\mathrm{ab}}$ & $10.50^{\mathrm{a}}$ & $9.80^{\mathrm{b}}$ & $9.50^{\mathrm{b}}$ & 0.21 \\
$\begin{array}{l}\text { Calcium } \\
\text { (mmol/L) }\end{array}$ & $10.00^{\mathrm{a}}$ & $10.10^{\mathrm{a}}$ & $9.90^{\mathrm{ab}}$ & $9.70^{\mathrm{b}}$ & 0.09 \\
$\begin{array}{l}\text { Alanine } \\
\text { transaminase } \\
\text { (iu/L) }\end{array}$ & $27.97^{\mathrm{a}}$ & $25.10^{\mathrm{ab}}$ & $23.30^{\mathrm{b}}$ & $22.93^{\mathrm{b}}$ & 1.15 \\
$\begin{array}{l}\text { Aspartate } \\
\text { transaminase } \\
\text { (iu/L) }\end{array}$ & $56.03^{\mathrm{a}}$ & $52.23^{\mathrm{a}}$ & $48.13^{\mathrm{b}}$ & $44.83^{\mathrm{b}}$ & 2.40 \\
$\begin{array}{l}\text { Alkaline } \\
\text { phosphatase } \\
\text { (iu/L) }\end{array}$ & $141.97^{\mathrm{a}}$ & $138.33^{\mathrm{a}}$ & $132.83^{\mathrm{ab}}$ & $124.83^{\mathrm{b}}$ & 3.73 \\
\hline
\end{tabular}

each other and similar $(\mathrm{P}>0.05)$ to rabbits on $\mathrm{T}_{2}$. There was no significant difference ( $P>0.05)$ between rabbits on $\mathrm{T}_{1}$ and $\mathrm{T}_{2}$ in Alanine transaminase. The lowest value in Alanine transaminase was observed in rabbits on $\mathrm{T}_{4}(22.93 \mathrm{iu} / \mathrm{L})$.

Rabbits on $\mathrm{T}_{1}$ recorded the highest Aspartate transaminase value $(56.03 \mathrm{iu} / \mathrm{L})$ and this differed significantly $(\mathrm{P}<0.05)$ from rabbits on $\mathrm{T}_{3}$ and $\mathrm{T}_{4}$ which were similar $(\mathrm{P}>0.05)$ to was no significant difference $(\mathrm{P}>0.05)$ between rabbits on $T_{1}$ and $T_{2}$ in Aspartate transaminase. The lowest value in Aspartate transaminase was observed in rabbits on $\mathrm{T}_{4}$. each other in Aspartate transaminase. There

Rabbits on $\mathrm{T}_{1}$ recorded the highest Alkaline phosphatase value $(141.79 \mathrm{iu} / \mathrm{L})$ and this different significantly $(\mathrm{P}<0.05)$ from rabbits on $\mathrm{T}_{4}$ which were similar $(\mathrm{P}>0.05)$ to rabbits on $\mathrm{T}_{3}$ in Alkaline phosphatase. There were no significant differences $(\mathrm{P}>0.05)$ among rabbits on $\mathrm{T}_{1}, \mathrm{~T}_{2}$ and $\mathrm{T}_{3}$ in Alkaline phosphatase. The lowest value in Alkaline phosphatase was observed in rabbits on $\mathrm{T}_{4}(124.83 \mathrm{iu} / \mathrm{l})$.

\section{DISCUSSION}

The serum urea values obtained in this study were lower than the range of 14.74-17.93 (mmol/L) reported by Etim and Oguike (2011) in rabbits fed Aspilia Africana, but within the normal range of $10.00-33.00(\mathrm{mmol} / \mathrm{L})$ reported by University of Pennsylvania school of veterinary medicine (2002) and Merck (2012) for rabbits. Higher blood urea levels have been associated with protein deficiency (Amaefula et al., 2005; Egu, 2018).

The cholesterol values obtained in this study were within the normal range of $0.30-2.10(\mathrm{mg} / \mathrm{dl})$ reported by Merck (2012) for rabbits and within the range of 1.47-2.63 (mg/dl) reported by Ilo and Egu (2018) for rabbits fed graded levels of ginger rhizome meal. Mufwa

and Mohammed et al. (2014) reported higher ranges of 33.12 - $40.00(\mathrm{mg} / \mathrm{dl})$ and $48.44-49.11(\mathrm{mg} / \mathrm{dl})$ respectively for rabbits.

The normal values of serum cholesterol obtained in this study implies that the dietary levels of Moringa oleifera leaf meal were safe for the rabbits, so rabbits fed 5-15\% MOLM may not face the risk of myocardial infraction usually associated with high blood cholesterol content and emaciation due to low serum cholesterol (Frandson, 2002).

The glucose values obtained in this study were within the normal range of 3.83-10.77 (mmol/L) reported by Ozkan et al. (2012) for rabbits. However, the glucose values in this study were much lower than the ranges of $8-15(\mathrm{mmol} / \mathrm{L})$ and $114.00-142.00(\mathrm{mmol} / \mathrm{L})$ reported by Mufwa et al. (2011) and Ewuola et al. (2012) respectively for rabbits. This disparity in glucose values may not be unconnected to 
the differences in age, sex, physiological and nutritional status of the rabbits. Normal glucose level in this study also indicated that there was no muscle wasting or catabolism of muscle tissue and that the rabbits were not living at the expense of their body reserve (Ilo \& Egu, 2018).

The calcium values obtained in this study were within the normal range of $8.00-15.50(\mathrm{mmol} / \mathrm{L})$ reported by the University of Pennsylvania School of Veterinary Medicine (2002) for rabbits and within the range of 9.67-10.13 (mmol/L) reported by Etim and Oguike (2011) for rabbits fed Aspilia africana. Serum calcium plays a vital role in the bones as they constitute the major mineral contents that help in the formation and strengthening of bones, and also mediates excitation and contraction of muscle fibre (Banerjee, 2007).

Alanine transaminase values obtained in this study were within the normal range of 10.00-45.00 (iu/L) reported by Merck (2012) for rabbits. However, ALT values in this study were higher than the range of 9.17-12.80 (iu/L) reported by Ahamefule et al. (2006) for rabbits fed sundried, ensiled and fermented cassava peel based diets. The normal levels of ALT indicate that the activities of osteoblasts were not affected because the blood level of ALT is usually a good indicator of the rate of bone formation (Ilo and Egu, 2018).

Aspartate transaminase values obtained in this study were within the range of 10-120 (iu/L) reported by the University of Pennsylvania School of Veterinary Medicine (2002). However, the AST values obtained in this study were higher than the range of 7.73-16.0 (iu/L) reported with sundried, ensiled and fermented cassava peel based diets, and higher than the range of 24.68-38.96 (iu/L) reported by Ilo and Egu (2018) for rabbits fed graded levels of ginger rhizome meal. Analysis of live enzymes (AST, ALT and ALP) activities give valuable diagnostic information for a number of disease conditions.

Alkaline phosphatase values obtained in this study were within the normal range of 17.00-192.00 (iu/L) reported by Merck (2012) for rabbits. However, the ALP values in this study were higher than the range of 5.92-8.38 (iu/L) reported by Ewuola et al. (2010) for rabbits fed dietary prebiotics and probiotics, and higher than the range of 44.25-56.30 (iu/L) as reported by Ilo and Egu, 2018, for rabbits fed graded levels of ginger rhizome meal. This disparity may be associated with the differences in physiological and nutritional status of the rabbits. Alkaline phosphatase assay is useful in the diagnosis of obstructive liver diseases (Murray et al., 2003). An increase in Alkaline phosphatase, Alanine transaminase and Aspartate transaminase values would signify necrosis or myocardial infarction which are all indicators of drug toxicity or harmful chemicals in the body (Nelson and Cox, 2005).

\section{CONCLUSION}

The results of this study showed that MOLM enhanced serum biochemical parameters of the rabbits at the level of $5 \%$ inclusion. There were variations in the values obtained, but without any deleterious effects on these parameters as they were within the normal ranges for rabbits.

\section{REFERENCES}

Adiele, J.G., Audu, H.O., Madu, T. \& Nwaogwugwu, R.O. (2005). Weather in 2005 at Umudike and its possible impact on root crops production. In: National Root Crops Research Institute Annual Report for 2005 pp. 252-255. Applied Rabbit Research, 12, 252-255.

Aduku, A.O. \& Olukosi, J.O. (1990). Rabbit management in the tropics living books series G.U. Publication, Abuja, KTPI.

Ahamefule, F.O., Eduok, G.O., Usman, A., Amaefule, K.U., Obua, B.E. \& Oguike, S.A. (2006). Blood biochemisry and haematology of weaner rabbits fed sundried, ensiled and fermented cassava peel based diets. Pakistan Journal of Nutrition, 5 (3), 248-253.

Akinmutumi, A.H. \& Anakebe, O.C. (2008). Performance of weaner rabbits fed graded levels of yam and sweet potato peel meal in place of maize-based diet. Pakistan Journal of nutrition, 7 (5), 700-704.

Amaefula, K.U., Iheukwumere, F.C. and Nwaokoro, C.C. (2005). A note on the growth performance and carcass characteristics of rabbits fed graded dietary levels of boiled pigeon pea seed (Cajanus cajan). Livestock Research for Rural Development, 17(5), 1-3

AOAC (2002). Official Methods of Analysis. Association of Official Analytical Chemists, Washington D.C., USA, $17^{\text {th }}$ edition.

Banerjee, G.C. (2007). A textbook of Animal Husbandary ( $8^{\text {th }}$ edition). Oxford and IBH publishing Co PVT Ltd New Delhi India.

Egu, U.N. (2016a). Effect of gonadotrophin (Diclair ${ }^{\circledR}$ ) on semen characteristics, body conformation and hormonal profile of mature male New Zealand White rabbits. Inter Journal of Agricultural Bioscience, 4 (6), 260-265

Egu. U.N. (2016b). Hematological and serum biochemical parameters of mature male turkeys treated with human menopausal gonadotrophin $\left(\right.$ Diclair $^{\circledR}$ ) for spermatogenesis. International Journal of Veterinary Science, 5(4), 274-279.

Egu, U.N. \& Okonkwo, J.C. (2016). Effect of gonadotrophin $\left(\right.$ Pergonal $\left.^{\circledR}\right)$ on hematological and serum biochemical parameters of mature Ouda rams treated for sperm production. International Journal of Environment and Agriculture Research, 2 (8),74-80.

Ephraim, K.O., Salami, H.H. \& Osewa, T.S. (2000). The effect of a grass extract of Ocimum gratissimum on haematological and biochemical parameters in rabbits. African journal of Biomodial Research, 3,175-179.

Esonu, B.O., Opara, M.N., Okoli, I.C., Obikanu, H.O., Udedibia, A.B.I. \& Iheshiulor, O.O.M. (2006). Physiological responses of laying birds to Neem (Azadirachta indica) leaf meal based diets; body 
weight, organ characteristics and hematology. Online Journal of Health and Allied Sciences, 5(2), 1-7.

Etim, N.N. \& Oguike, M.A. (2011). Hematology and serum biochemistry of rabbit does fed Aspilia Africana. Nigerian Journal of Agriculture, Food and Environment, 7 (4), 121-127.

Ewuola, E.O., Sokumbo, A.O., Alba, O., Omotosho, J.O. \& Omoniyi, A.B. (2010). Hematology and serum biochemistry of weaned rabbits fed dietary prebiotics and probiotics. In, Proceedings of $35^{\text {th }}$ Conference of Nigerian Society for Animal Production, $14^{\text {th }}-17^{\text {th }}$ March, University of Ibadan.

Ewuola, E.O., Jimoh, O.A., Atuma, O.V., Soipe, D.O. (2012). Hematological and serum biochemical responses of growing rabbits fed graded levels of Moringa oleifera leaf meal. Proceedings of $10^{\text {th }}$ World Rabbit Congress, $3^{\text {rd }}-6^{\text {th }}$ September Sharm ElSheikh-Egypt, 679-683.

Farooq, M., Faisal, S., Mian, M.A., Durrani, F.R. \& Arshad, M. (2001). Status of Boriler breeders in Abbottabad and Mansehra. Sarhad Journal of Agriculture, 17,489495.

Frandson, R.D. (2002). Anatomy and Physiology of Farm Animals $3^{\text {rd }}$ Ed. Published by Bialiere Tindal, London, pp, 32-54.

Gadzirayi, C.T., Masamba, B., Mupangwa, J.F. and Washaya, S. (2012). Perforamcne of Broiler Chickens Fed on Mature Moringa oleifera Leaf Meal as a Protein Supplement to Soyabean Meal. International Journal of Poultry Science, 11 (1),5-10.

Ilo, S.U. \& Egu, U.N. (2018). Effect of graded levels of ginger rhizome (Zingiber officinale) meal on serum biochemistry of pubertal New Zealand White rabbits. Journal of animal Science and Veterinary Medicine, 3 (4), 133-139.

Kohn, R.A. \& Allen, M.S. (1995). Enrichment of proteolytic activity relative to nitrogen in preparation from the rumen for in vitro studies. Animal

Food science and Technology, 52 (112), 1-4.

Madubuike, F.N. \& Ekenyem, B.U. (2000). Ruminant Animal Production and Handling in the Tropics, Alphabet Publishers Owerri - Nigeria.

Martin, L.P. (2007). The Moringa tree Echo. North Fort Myers. FL 33917, USA. Available at http,//www.echonet.org.

Martin $^{\text {b }}$, E.A. (2007). Concise medical dictionary ( $7^{\text {th }}$ ed) Oxford. England. Oxford University press.

Merck (2012). The Merck veterinary manual. $12^{\text {th }}$ Edition Merck and Co. Inc. white House station N.J., USA. Pp 1470-1492.

Mohammed, G., Igwebuike, J.U., Adamu, S.B., Alade, N.K. \& Asheikh, L.G. (2014). Effect of feeding different blood rumen content mixtures on blood parameters and carcass measurements of growing rabbits. International Journal of Science and Nature, 5 (1), 61-66.

Mufwa, B.J., Yakubu, B., Kibon, A. \& Zaklag, D.U. (2011). Hematological and biochemical indices of growing rabbits fed graded levels of brewers dried grains. Journal of Agriculture and Veterinary Science, vol. 3.
Murray, R.K., Granner, D.R., Mayes, P.A. \& Rodwell, V.W. (2003). Herper's illustrated biochemistry $26^{\text {th }}$ edn. McGraw hill companies, Inc. USA, pp. 693.

Nelson, D.L. \& Cox, M.M. (2005). Lehninger Principles of Biochemistry $4^{\text {th }}$ Edn. W.H. Freeman and Company New York. Pp. 119

Nouman, W., Basra, S.M.A., Siddiqui, M.T., Yasmeen, A., Gull, T. \& Alcaydic, M.A.C. (2013). Potential of Moringa oleifera L. as living fodder crop, A review Turkish Journal of Agriculture and Forestry, 37 (1), $1-14$.

Obi, I.U. (1990). Statistical Methods of Detecting Differences between Treatment Means. Snap press $2^{\text {nd }}$ Ed. Enugu, Nigeria 24-35.

Olupona, J.A. \& Balogun, O.A. (2014). Nutrient utilization by rabbits fed brewers dried grains from different portions of barley, maize and sorghum, Nigerian Journal of Animal Production, 31, 89-193.

Ozkan, C., Kaya, A. \& Akgiil, Y. (2012). Normal values of hematological and some biochemical parameters in serum and urine of New Zealand White rabbits. World Rabbit Science. 20, 253-259.

Prathap, D.P. \& Ponnusamy, K.A. (2007). Factors influencing the attitude of farmers of Jamill Nada, India, towards farming. Livestock Research for Rural Development, 19 (6),51-54.

Randox (2006). www.Randox.com/Randox.Laboratory Ltd.Users' Manual.

Solivia, C.R., Kreuzer, M., Foidl, G., Mach-Miiler, A. \& Hess, H.O. (2004). Feeding value of whole and extracted Moringa oleifera leaves for ruminants and their effects. Ruminant Animal Feed Science and Technology, 118 (1),47-62.

Soyebo, K.O. (2006) Constraints against wide spread rabbit keeping among house hold in Osun and Ogun states. Implication for family economic empowerment. Journal of Applied Science and Research, 2 (12), 1244-1247

Spore (2007). Rearing rabbits. Family farming: the future of the world. Spore 131 CTA publication.

Steel, R.G.D. \& Torrie, J.H. (1980). Principles and Procedures of Statistics. A Biometric Approach $2^{\text {nd }}$ Ed. M.C. Graw-Hill Book Co. Inc. New York.

Stephen, K., Bangert, M.A., William, J., Marshall, A. \& William, L. (2008). Clinical Biochemistry Metabolic and Clinical Aspects, Elsevier, Philadelphia.

Sudha, P., Asdaq, S.M., Dhamingi, S.S. \& Chan-drakala, G.K. (2010). Imuno-Modulatory Activity of Methanolic Leaf Extract of Moringa oleifera in Animals. Indian Journal of Physiology and Pharmacology, 54 (2),133-140.

University of Pennsylvania School of Veterinary Medicine (2002). Rabbit reference range.

Yang, R.Y. \& Tsou, S.C.S. (2006). Enhancing iron bioavailability of vegetables through proper preparation principles and applications. Journal of International cooperation, 1, 107-119.

Article history:

Received: July 7, 2021,

Revised: Dec. 23, 2021,

Accepted: Dec.30, 2021 